(BEI) Tahun 2015-2017

\title{
PENGARUH FINANCIAL DISTRESS, DEBT DEFAULT, DAN AUDIT TENURE TERHADAP PENERIMAAN OPINI AUDIT GOING CONCERN PADA PERUSAHAAN MANUFAKTUR YANG TERDAFTAR DI BURSA EFEK INDONESIA (BEI) TAHUN 2015-2017
}

\author{
Priska Liliani \\ Universitas Bina Nusantara \\ priscaaliliani19@gmail.com
}

\begin{abstract}
Manufacturing companies are a sector that is quite important for the development of the country's economy. In Indonesia, there are more companies in the manufacturing sector listed on the Indonesia Stock Exchange (IDX). With this larger number of companies, companies in the manufacturing sector have significant industrial influence as well as significant stock fluctuations on the IDX. The purpose of this study aims to analyze the effect of financial distress, debt default, and audit tenure on going concern audit opinion. To support this research, the author uses a sample of manufacturing companies listed on the Stock Exchange as the object of research. From the results of observations for 3 years, namely from 2015 - 2017, 28 samples were obtained to be studied according to the observation period so that the number ofunits of analysis was equal to 84. Based on tests carried out using logistic regression, empiricalevidence was obtained that the financial distress variable had a positive influence. which is significant to the acceptance of going concern audit opinion. The debt default variable has no significant effect on the going concern audit opinion acceptance. The Audit Tenure variable does not have a significant effect on the going concern audit opinion acceptance.
\end{abstract}

Keywords: Financial Distress, Debt Default, Audit Tenure, Audit Opinion Going Concern

\begin{abstract}
ABSTRAK
Perusahaan manufaktur merupakan sektor yang cukup penting bagi pembangunan perekonomian negara. Di Indonesia, perusahaan pada sektor manufaktur yang terdaftar pada Bursa Efek Indonesia (BEI) berjumlah lebih banyak jika dibandingkan dengan sektor perusahaan yang lain. Dengan jumlah perusahaan yang lebih banyak ini, perusahaan pada sektor manufaktur memiliki pengaruh industri serta fluktuasi saham yang cukup signifikan pada BEI. Tujuan penelitian ini bertujuan untuk menganalisis pengaruh financial distress, debt default, dan audit tenure terhadap opini audit going concern. Untuk mendukung penelitian ini, penulis menggunakan sampel perusahaan manufaktur yang terdaftar di BEI sebagai objek penelitian. Dari hasil pengamatan selama 3 tahun yakni dari tahun 2015 2017, diperoleh 28 sampel yang akan diteliti sesuai periode pengamatan sehingga jumlah unit analisis sama dengan 84. Berdasarkan pengujian yang dilakukan dengan menggunakan regresi logistik, didapatkan bukti empiris bahwa variabel financial distress memiliki arah pengaruh positif yang signifikan terhadap penerimaan opini audit going concern. Variabel debt default tidak memiliki pengaruh signifikan terhadap penerimaan opini audit going concern. Variabel Audit Tenure tidak memiliki pengaruh signifikan terhadap penerimaan opini audit going concern.
\end{abstract}

Keywords : financial distress, debt default, audit tenure, opini audit going concer 


\section{PENDAHULUAN}

Perusahaan adalah bagian utama dalam dunia perekonomian yang berperan sebagai penyedia barang dan jasa bagi masyarakat. Perusahaan dipimpin oleh sekelompok orang (management) yang ditugaskan untuk mengatur agar operasional perusahaan berjalan baik dan sesuai dengan tujuan yang diinginkan pemiliknya (shareholder). Dalam melakukan tugasnya mengatur operasional perusahaan, management juga dituntut untuk membuat laporan keuangan secara berkala sebagai bentuk pertanggung jawaban kepada shareholder dan pihak-pihak yang berkepentingan (stakeholder). Tujuan utama dari dibuatnya laporan keuangan adalah sebagai sumber informasi atas kinerja, posisi keuangan, dan perubahan posisi keuangan dari suatu perusahaan yang dapat digunakan untuk berbagai keperluan, salah satu contohnya adalah untuk pengambilan keputusan investasi. Dalam hal ini laporan keuangan berperan sebagai sumber informasi dalam pengambilan keputusan, salah satunya adalah keputusan investasi. Pihak yang melakukan investasi (Investor) memiliki harapan memperoleh keuntungan dari investasinya baik dalam bentuk dividen maupun capital gain. Akan tetapi, keuntungan tersebut hanya dapat terwujud apabila perusahaan dapat beroperasi dengan baik serta mempertahankan kelangsungan hidupnya (going concern). Kelangsungan hidup perusahaan menjadi sorotan utama para stakeholder, terutama para investor. (Listantri \& Mudjiyanti, 2016) menyatakan: "Going concern adalah kelangsungan hidup suatu entitas bisnis. Suatu entitas dianggap akan mampu mempertahankan usahanya dalam jangka waktu yang panjang, dengan pengertian bahwa entitas tersebut tidak akan mengalami kebangkrutan dalam jangka waktu yang pendek.”. Pada dasarnya, kemampuan perusahaan untuk terus beroperasi (going concen) seringkali dihubungkan dengan kemampuan management untuk mengelola operasional perusahaan agar dapat bertahan dalam bisnisnya. Ketika terdapat masalah dalam perekonomian perusahaan, para pemegang saham mengharapkan dapat mendapatkan early warning akan kegagalan keuangan perusahaan, salah satunya adalah melalui pernyataan yang diberikan pihak independen yaitu auditor eksternal. Pernyataan Standar Auditing (PSA) 30 paragraf 02 SA Seksi 341 menyatakan bahwa "auditor bertanggung jawab untuk mengevaluasi apakah terdapat kesangsian besar terhadap kemampuan entitas dalam mempertahankan kelangsungan hidupnya 
Pengaruh Financial Distress, Debt Default, dan Audit Tenure Terhadap Penerimaan Opini Audit Going Concern Pada Perusahaan Manufaktur Yang Terdaftar Di Bursa Efek Indonesia (BEI) Tahun 2015-2017

dalam periode waktu pantas, tidak lebih dari satu tahun sejak tanggal laporan keuangan yang sedang diaudit”. Oleh sebab itu, selain menilai dan memberikan informasi kewajaran atas laporan keuangan yang disajikan oleh management, auditor juga diharapkan dapat menilai dan memberikan informasi tentang kemampuan perusahaan untuk going concern kepada para pengguna laporan keuangan dengan didasarkan pada kondisi dan peristiwa pada saat audit dilakukan. Meskipun begitu, auditor tidak dibebankan tanggung jawab atas kondisi dan peristiwa yang akan terjadi setelah periode audit. Auditor menuangkan informasi going concern dengan menambah paragraf penjelas pada opini audit mengenai pertimbangan auditor bahwa terdapat ketidakpastian signifikan atas kelangsungan hidup perusahaan dalam menjalankan operasinya. Opini going concern ini sangat berguna untuk para pengguna laporan keuangan, khususnya bagi investor agar terhindar dari kesalahan keputusan investasi sedangkan bagi management agar dapat segera mengambil tindakan perbaikan dalam bisnisnya. Dalam menilai kelangsungan hidup perusahaan, auditor mempertimbangkan berbagai aspek, khususnya efek atas pemberian informasi tersebut. Pasalnya opini going concern yang dimaksudkan untuk dapat menjadi evaluasi bagi management seringkali minimbulkan masalah tambahan bagi perusahaan. Venuti (dalam Yanuariska \& Ardiati 2018) menyatakan bahwa hal ini didukung dengan hipotesis self-fulfilling prophecy yang beranggapan bahwa "jika auditor memberikan opini going concern, maka perusahaan akan menjadi lebih cepat bangkrut karena akan menyebabkan investor membatalkan investasinya atau kreditor menarik dananya". Meskipun demikian, informasi audit terkait going concern perlu diungkapkan dengan tepat sebagai bentuk transparansi perusahaan dan untuk kepentingan para stakeholder. Aspek utama dalam memprediksi kelangsungan hidup perusahaan adalah dengan menilai kondisi operasional perusahaan. Faktor utama yang digunakan untuk menilai operasional perusahaan adalah pendapatan perusahaan, apabila ada kemungkinan masalah pada pendapatan maka perusahaan tersebut dapat dinilai tidak beroperasional dengan baik. Perusahaan yang tidak beroperasional dengan baik dapat diindikasikan mengalami financial distress. Financial distress adalah keadaan dimana kondisi keuangan sebuah perusahaan selama periode tertentu menghasilkan laba bersih (net 
profit) negatif dan arus kas operasi perusahaan tidak mencukupi untuk melakukan perbaikan. Kondisi keuangan financial distress ini dinilai dapat memprediksi kebangkrutan lebih akurat bahkan apabila dibandingkan dengan opini audit tahun lalu. Aspek lain yang juga sering digunakan dalam menilai kelangsungan hidup perusahaan adalah kegagalan perusahaan dalam membayarkan kewajiban hutangnya (debt default). (Chen \& Church, 1992) dalam Praptitorini \& Januarti (2011) mendifisikan Debt default sebagai kegagalan debitor (perusahaan) untuk membayar hutang pokok dan/atau bunganya pada waktu jatuh tempo. Kondisi default perusahaan umumnya disebabkan oleh kesulitan keuangan yang menyebabkan kurangnya arus kas untuk membayar hutang yang jatuh tempo. Status debt default diharapkan dapat meningkatkan kemungkinan auditor untuk memberikan early warning dengan mengeluarkan opini going concern. Opini auditor atas laporan keuangan merupakan bagian penting dalam laporan keuangan yang menyatakan bahwa laporan keuangan tersebut sudah disajikan dengan wajar dan sesuai dengan standar yang berlaku. Opini auditor diharapkan bebas dari bias sehingga diperlukan auditor yang berkualitas dan independen dalam melakukan pemeriksaan.
Independensi auditor ditentukan oleh berbagai faktor, salah satunya adalah melalui audit tenure. Audit tenure merupakan lama hubungan kerjasama perusahaan dengan Kantor Akuntan Publik (KAP). Pada saat perusahaan dengan KAP sudah memiliki hubungan kerjasama audit yang cukup lama, perusahaan dapat dipandang sebagai sumber penghasilan untuk KAP dan secara potensial dapat mengurangi independensi. Dengan berkurangnya independensi auditor maka objektivitas auditor juga akan berkurang dan hasil evaluasi menjadi tidak akurat. Di sisi lainnya, lamanya perikatan KAP dengan perusahaan juga dapat dianggap sebagai suatu keuntungan dimana auditor dapat lebih memahami operasional perusahaan dan memperdalam prosedur yang diharapkan untuk dapat meningkatkan keakuratan auditor dalam melakukan audit dan pelaporan. Tambahin tentang efeknya terhadap audit going concern Penelitian yang berkaitan dengan analisis penerimaan opini audit going concern dan faktor-faktor yang mempengaruhinya telah dilakukan oleh beberapa peneliti di antaranya (Azizah \& Anisykurlillah, 2014), (Elmawati \& Yuyetta, 2014), (Handhayani \& Budiartha, 2015),(Harris \& Meiranto, 2015), (Listantri \& Mudjiyanti, 2016), (Imani, Nazar, \& Budiono, 2017), 
Pengaruh Financial Distress, Debt Default, dan Audit Tenure Terhadap Penerimaan Opini Audit Going Concern Pada Perusahaan Manufaktur Yang Terdaftar Di Bursa Efek Indonesia (BEI) Tahun 2015-2017

(Syahputra \& Yahya, 2017), Yanuariska \& Ardiati (2018). Penelitian yang telah dilakukan tersebut tidak menghasil hipothesis yang konsisten. Berdasarkan hasil penelitian terdahulu tersebut, maka peneliti melakukan penelitian ini dengan tujuan meneliti kembali pengaruh financial distress, debt default, dan audit tenure terhadap opini audit going concern. Penelitian dilakukan dengan menggunakan sampel perusahaan manufaktur dengan harapan akan menjelaskan pengaruh financial distress, debt default, dan audit tenure terhadap penerimaan opini audit going concern. Perusahaan manufaktur merupakan sektor yang cukup penting bagi pembangunan perekonomian negara. Di Indonesia, perusahaan pada sektor manufaktur yang terdaftar pada Bursa Efek Indonesia (BEI) berjumlah lebih banyak jika dibandingkan dengan sektor perusahaan yang lain. Dengan jumlah perusahaan yang lebih banyak ini, perusahaan pada sektor manufaktur

\section{TELAAH LITERATUR}

\section{Going Concern}

Going concern diartikan sebagai kelangsungan hidup suatu entitas untuk dapat terus menjalankan operasionalnya. (Listantri \& Mudjiyanti, 2016) menyatakan: "Going concern adalah kelangsungan hidup suatu entitas bisnis. memiliki pengaruh industri serta fluktuasi saham yang cukup signifikan pada BEI. Untuk mendukung penelitian ini, peneliti menggunakan sampel perusahaan manufaktur yang terdaftar di BEI sebagai objek penelitian. Berdasarkan pembahasan latar belakang penelitian diatas, penelitian ini ditujukan untuk menganalisis pengaruh dari faktor-faktor yang diduga terhadap penerimaan opini going concern. Identifikasi masalah penelitian adalah sebagai berikut :

1. Diduga adanya pengaruh financial distress terhadap penerimaan opini audit going concern pada perusahaan manufaktur

2. Diduga adanya pengaruh debt default terhadap penerimaan opini audit going concern pada perusahaan manufaktur

3. Diduga adanya pengaruh audit tenure terhadap penerimaan opini audit going concern pada perusahaan manufaktur

Suatu entitas dianggap akan mampu mempertahankan usahanya dalam jangka waktu yang panjang, dengan pengertian bahwa entitas tersebut tidak akan mengalami kebangkrutan dalam jangka waktu yang pendek.”. Dalam proses audit, 
auditor tidak hanya menilai kewajaran penyajian laporan keuangan, tetapi juga bertanggung jawab untuk mengevaluasi kelangsungan hidup perusahaan. Auditor harus memutuskan apakah mereka yakin bahwa perusahaan akan bisa bertahan dimasa yang akan datang. Penilaian ini dapat dilakukan dengan mengevaluasi akibat setiap transaksi yang berpengaruh signifikan terhadap kegiatan operasional perusahaan. Ada 4 kondisi dan peristiwa yang dapat diidentifikasi dan dijadikan sebagai bahan pertimbangan oleh auditor, yaitu :

a) Kecenderungan-Kecenderungan

Negatif (Negative Trends).

Negative Trends diartikan pada penurunan kondisi operasional perusahaan yang dapat berdampak pada kelangsungan hidup perusahaan. Misalnya, kerugian operasi yang berulang terjadi, kekurangan modal kerja, arus kas operasional negatif, rasio keuangan yang negatif, key performance indicator yang bernilai buruk.

b) Indikasi kesulitan keuangan

Kesulitan keuangan dapat disebabkan oleh faktor eksternal seperti keadaan ekonomi dan juga faktor internal yang menyangkut kebijakan dan strategi perusahaan. Misalnya, kegagalan dalam memenuhi kewajiban membayar utang, penunggakan dalam membayar dividen, timbulnya kebutuhan untuk restrukturisasi utang, adanya inisiasi untuk menjual cepat sebagian asset yang dimilikinya.

c) Persoalan Internal (Internal Issues).

Persoalan internal mengarah pada masalah yang timbul dari dalam perusahaan karena adanya konflik atau kesalahan dalam strategi bisnis. Misalnya, pemogokan kerja yang dilakukan oleh buruh, ketergantungan besar atas kesuksesan proyek tertentu, komitmen jangka panjang yang tidak bersifat ekonomis, kebutuhan untuk memperbaiki operasi yang signifikan.

d) Persoalan Eksternal (External Issues) Persoalan eksternal timbul dikarenakan adanya kejadian tertentu yang berasal dari luar perusahaan. Misalnya, adanya tuntutan hukum atau gugatan peradilan yang berpotensi mengganggu kelangsungan hidup perusahaan, berlakunya undang undang atau permasalahan lainnya yang berpotensi membatasi atau menghentikan operasional perusahaan baik secara keseluruhan maupun sebagian, kehilangan hak kelola lisensi-copyright-dan-paten penting, kehilangan pelanggan atau pemasok utama, kerugian akibat bencana besar seperti gempa bumi banjir kekeringan - dan - force majeur lainnya yang tidak diasuransikan atau 
Pengaruh Financial Distress, Debt Default, dan Audit Tenure Terhadap Penerimaan Opini Audit Going Concern Pada Perusahaan Manufaktur Yang Terdaftar Di Bursa Efek Indonesia (BEI) Tahun 2015-2017

diasuransikan tetapi nilai

\section{Opini Audit Going Concern}

"Opini audit going concern adalah opini yang menyatakan bahwa dalam dikeluarkan auditor dengan menambah paragraf penjelas mengenai pertimbangan auditor bahwa terdapat ketidakmampuan atau ketidakpastian signifikan atas kelangsungan hidup perusahaan dalam menjalankan operasinya pada masa mendatang” (Muttaqin \& Sudarno, 2012). Laporan audit yang memiliki modifikasi paragraf penjelas mengenai going concern merupakan suatu indikasi bahwa dalam penilaian auditor terdapat resiko perusahaan tidak dapat bertahan dalam bisnisnya. Banyak penelitian yang menyatakan "setelah dikeluarkannya SAS 59 tentang going concern, sekitar 40-50\% dari perusahaan yang mengalami kebangkrutan ternyata telah menerima opini audit going concern atas laporan keuangan terakhir sebelum kebangkrutan". Meskipun auditor diharapkan untuk dapat menilai kelangsungan hidup suatu perusahaan, auditor tidak bertanggung jawab untuk memprediksi kondisi atau peristiwa yang datang dimasa depan. Auditor melakukan tugasnya yaitu monitoring and controlling atas kinerja manajemen dengan cara memerika kewajaran laporan keuangan yang dihasilkan. Auditor melakukan proses audit pertanggungannya tidak memadai.

terhadap kewajaran laporan keuangan yang terdiri dari neraca, laporan laba rugi, laporan perubahan modal, dan laporan arus kas termasuk catatan atas laporan keuangan yang kemudian akan memberikan pendapat atas pekerjaan auditnya dalam bentuk opini audit. SPAP seksi 341, menyatakan apabila "auditor tidak menyangsikan kemampuan satuan usaha dalam mempertahankan kelangsungan hidupnya (going concern) dalam jangka waktu pantas, maka auditor memberikan pendapat wajar tanpa pengecualian". Apabila auditor menyangsikan kemampuan satuan usaha dalam mempertahankan kelangsungan hidupnya dalam jangka waktu pantas, maka auditor wajib mengevaluasi rencana manajemen. Auditor akan memberikan pendapat wajar tanpa pengecualian dengan paragraf penjelas jika rencana manajemen perusahaan secara efektif dapat dilaksanakan untuk mengatasi dampak dari kondisi dan peristiwa yang menyebabkan kesangsian auditor tentang kelangsungan usahanya. Apabila auditor menganggap bahwa rencana manajemen tidak secara efektif dapat mengurangi dampak negatif kondisi atau peristiwa tersebut maka auditor menyatakan opini tidak memberikan pendapat. Apabila auditor menyangsikan kelangsungan hidup 
perusahaan dan auditor berkesimpulan bahwa manajemen tidak membuat pengungkapan dan mengenai sifat, dampak, kondisi dan peristiwa yang menyebabkan auditor menyangsikan kelangsungan hidup perusahaan maka auditor menyatakan opini wajar dengan pengecualian. Jika

\section{Financial Distress}

Financial distress adalah kondisi dimana terjadi penurunan perekonomian yang dialami oleh suatu perusahaan, yang dapat menyebabkan terjadinya kebangkrutan ataupun likuidasi. Financial distress merupakan kondisi dimana keuangan perusahaan dalam keadaan tidak sehat atau sedang mengalami kesulitan. Kondisi keuangan perusahaan menggambarkan kesehatan perusahaan sesungguhnya (Astuti \& Darsono, 2012). Laporan keuangan adalah media yang dapat dipakai untuk menilai kondisi keuangan perusahaan yang terdiri dari neraca, laporan laba rugi, laporan laba yang ditahan, dan laporan posisi keuangan. Financial distress umumnya terjadi sebelum suatu entitas mengalami kebangkrutan. Kebangkrutan umumnya dipicu oleh kekurangan atau ketidakcukupan dana yang dimiliki perusahaan sehingga menyebabkan perusahaan mengalami permasalahan dalam operasionalnya atau gagal mencapai tujuan ekonominya, yaitu mendapatkan laba. Pada saat perusahaan sulit untuk mendapatkan laba, maka perusahaan pengungkapan di dalam rencana manajemen tidak memadai pengungkapannya dan tidak dilakukan penyesuaian, meskipun dampaknya sangat material dan terdapat penyimpangan dari prinsip akuntansi yang berlaku, maka auditor akan memberikan opini tidak wajar.

memiliki potensi yang besar untuk bangkrut karena oleh karena laba, perusahaan dapat membayarkan kewajibannya, membiayai operasionalnya, dan mengembangkan usahanya. Permasalahan kondisi keuangan ini disebut juga financial distress. Semakin memburuk atau terganggunya kondisi keuangan suatu perusahaan maka semakin besar kemungkinan perusahaan menerima opini audit going concern. Berlaku juga sebaliknya, apabila perusahaan memiliki kondisi keuangan yang baik, maka kecil kemungkinan untuk menerima opini audit going concern. Kesulitan keuangan dapat disebabkan oleh faktor internal maupun eksternal. Dampak utama dari financial distress adalah dapat menyebabkan perusahaan sulit untuk dapat membayarkan kewajiban hutang yang dimilikinya. Pada umumnya perusahaan yang mengalami financial distress akan menghadapi kondisi arus kas negatif yang menyebabkan ketidak mampuan untuk memenuhi jadwal atau kegagalan bayar hutang pada saat jatuh tempo. Dampak lain yang dapat terjadi adalah perusahaan akan mengalami kondisi 
Pengaruh Financial Distress, Debt Default, dan Audit Tenure Terhadap Penerimaan Opini Audit Going Concern Pada Perusahaan Manufaktur Yang Terdaftar Di Bursa Efek Indonesia (BEI) Tahun 2015-2017

tidak solvable (insolvency). Rumus Z- keuangan perusahaan untuk dapat score Altman diperkenalkan oleh Edward memprediksi probabilitas bahwa sebuah I. (Altman, 1968)dalam penelitiannya perusahaan dapat melanjutkan usahanya memprediksi kebangkrutan bagi atau mengalami kebangkrutan. Fungsi perusahaan manufaktur yang go public. Z- diskriminan yang dihasilkan dari penelitian score menguraikan lima rasio keuangan, yang dikembangkan Altman, yaitu :

dimana semua data diperoleh dari laporan

Di mana :

$$
\text { Z-Score }=1.2 \mathrm{X} 1+1.4 \mathrm{X} 2+3.3 \mathrm{X3}+0.6 \mathrm{X} 4+0.999 \mathrm{X5}
$$

$\mathbf{X 1}=$ working capital $/$ total asset $\mathbf{X 4}=$ market value of equity / book value of

$\mathbf{X} \mathbf{2}=$ retained earnings $/$ total asset debt

$\mathbf{X 3}=$ earning before interest and taxes / $\mathbf{X 5}=$ sales $/$ total asset

total asset

Tabel 1 Penafsiran Hasil Z-Score

\begin{tabular}{|c|c|}
\hline Keterangan & Nilai Z \\
\hline Tidak bangkrut (Safe Area) & Z $>2.99$ \\
\hline Rawan Bangkrut (Grey Area) & $1.80<\mathrm{Z}<2.99$ \\
\hline Bangkrut (Distress Area) & $<1.80$ \\
\hline
\end{tabular}

Sumber : Edward I. (Altman, 1968)

Model yang telah dikembangkan Altman ini mengalami sebuah revisi, dikarenakan masih banyak perusahaan manufaktur yang belum go public. (Altman, 1968) kemudian mengembangkan model untuk menilai financial distress bagi perusahaan yang belum go public dengan

Di mana :

$$
\mathrm{Z}-\mathrm{Score}=0.717 \mathrm{X} 1+0.847 \mathrm{X} 2+3.107 \mathrm{X3}+\mathbf{0 . 4 2 0} \mathrm{X} 4+0.998 \mathrm{X5}
$$

$\mathbf{X 1}=$ working capital / total asset

$\mathbf{X} \mathbf{2}=$ retained earnings $/$ total asset

$\mathbf{X 3}=$ earning before interest and taxes /

total asset

$\mathbf{X 4}=$ book value of equity / book value of debt

$\mathbf{X 5}=$ sales $/$ total asset

Penafsiran Hasil altman revised Z-score dikategorikan sebagai berikut : 
Tabel 2 Penafsiran Hasil Revised Z-Score

\begin{tabular}{|c|c|}
\hline Keterangan & Nilai Z \\
\hline Tidak bangkrut (Safe Area) & Z $>2.90$ \\
\hline Rawan Bangkrut (Grey Area) & $1.23<\mathrm{Z}<2.90$ \\
\hline Bangkrut (Distress Area) & $\mathrm{Z}<1.23$ \\
\hline
\end{tabular}

Definisi dari kelima rasio yang

kumulatif.

Biasanya

yang

dikembangkan Altman tersebut adalah menguntungkan perusahaan sebagai berikut:

a) Rasio X1 = working capital dibagi dengan total assets digunakan untuk mengukur likuiditas asset perusahaan relatif terhadap total kapitalisasinya. Asset lancar bersih atau working capital diartikan sebagai total asset lancar dikurangi total kewajiban lancar. Pada dasarnya pada saat perusahaan mengalami kesulitan keuangan, working capital akan turun lebih cepat dari pada total aktiva menyebabkan rasio ini turun. Semakin rendah nilai dari rasio ini, maka perusahaan terindikasi mengalami financial distress.

b) Rasio X2 = retained earnings dibagi dengan total assets digunakan untuk mengukur keuntungan kumulatif. Pada beberapa tingkat, rasio ini dapat menggambarkan umur perusahaan, karena semakin muda perusahaan, semakin sedikit nilai rasionya yang dikarenakan sedikitnya waktu yang dimiliki untuk membangun laba perusahaan yang lebih berumur initidak mengherankan, karena pemberian tingkat kegagalan yang tinggi kepada perusahaan yang lebih muda merupakan hal yang wajar. Bila perusahaan mulai merugi, tentu saja nilai dari total laba mulai turun. Bagi banyak perusahaan, nilai laba ditahan dan rasio X2 akan menjadi negatif.

c) Rasio X3 = earning before interest and tax dibagi dengan total assets digunakan untuk mengukur nilai produktivitas yang sebenarnya dari asset perusahaan. Rasio ini juga dapat digunakan untuk mengukur kemampuan perusahaan menghasilkan laba, yaitu tingkat pengembalian dari aktiva, yang dihitung dengan membagi laba sebelum bunga dan pajak (EBIT) tahunan perusahaan dengan total aktiva pada neraca akhir tahun. Bila rasio ini lebih besar dari rata-rata tingkat bunga yang dibayar, maka berarti perusahaan menghasilkan uang yang lebih banyak dari pada bunga pinjaman. 
d) Rasio X4 = book Value of total Equity dibagi dengan book value of total debt rasio ini menunjukan kemampuan perusahaan untuk memenuhi kewajiban kewajiban dari nilai buku modal sendiri.

e) Rasio X5 = sales dibagi dengan total assets digunakan untuk mengukur kemampuan manajemen dalam menghadapi kondisi persaingan. Rasio

\section{Debt Default}

Berpaduan dengan teori agensi, prinsipal mengacu pada laporan yang dibuat oleh auditor dalam menilai kinerja agen dan mengetahui keadaan perusahaan. Untuk menghasilkan laporan yang handal, auditor perlu melakukan pemeriksaan pada setiap kegiatan usaha, khususnya pada hutang perusahaan. Perusahaan menjalankan dan mengembangkan usahanya dengan melakukan ekspansi dan inovasi yang dapat menyebabkan pada peningkatan kewajiban (debt). Hutang perusahaan yang meningkat menyebabkan meningkatnya juga beban bunga yang harus dibayarkan perusahaan, apabila operasional perusahaan tidak berjalan dengan baik maka perusahaan mungkin akan kesulitan untuk membayarkan pinjamannya ataupun bunga dari pinjamannya saat jatuh tempo ataubisa dikatakan mengalami default. (Irfana \& Muid, 2012) menyatakan bahwa "ketika suatu perusahaan memiliki hutang yang tinggi, maka kas yang ada di perusahaan akan diarahkan untuk menutup hutangyang ini menunjukan apakah perusahaan menghasilkan volume bisnis yang cukup dibandingkan investasi dalam total aktivanya. Sales merupakan variabel penting dalam penelitian dikarenakan merupakan penentu utama apakah perusahaan beroperasional dengan baik.

dimiliki perusahaan yang dampaknya akan mengganggu kegiatan operasional perusahaan. Ketika perusahaan kesulitan untuk memenuhi hutangnya, auditor akan memberikan status default untuk perusahaan tersebut.” (Chen \& Church, 1992) dalam Praptitorini \& Januarti (2011) menyatakan bahwa Debt default didefinisikan sebagai kegagalan debitor (perusahaan) untuk membayar hutang pokok dan/atau bunganya pada waktu jatuh tempo. Dalam PSA 30, indikator going concern yang banyak digunakan auditor dalam memberikan keputusan opini audit adalah kegagalan dalam memenuhi kewajiban hutangnya (debt default). Pernyataan tersebut juga didukung oleh penelitian yang dilakukan oleh (Harris \& Meiranto, 2015) yang menyatakan bahwa debt default berpengaruh signifikan terhadap opini audit going concern. (Chen \& Church, 1992) dalam Praptitorini \& Januarti (2011) mengungkapkan bahwa sebuah perusahaan dapat dikategorikan 
dalam keadaan debt default apabila mengalami salah satu kondisi ini :

1. Perusahaan tidak berhasil atau gagal dalam membayar kewajiban pokok atau bunga yang timbul

2. Adanya pelanggaran perjanjian utang, jika pelanggaran perjanjian tersebut

\section{Audit Tenure}

Audit Tenure adalah jangka waktu hubungan kerjasama yang terjalin antara satu entitas dengan Kantor Akuntan Publik (KAP) yang sama. Hubungan yang terjalin ini dikarenakan berbagai hal, umumnya dari sisi auditee berasumsi agar audit yang dilakukan pada tahun-tahun selanjutnya dapat berjalan lebih lancar dan singkat karena auditor sudah mengenal ruang lingkup perusahaan, sedangkan dari sisi auditor umumnya berasumsi untuk menghindari penurunan pendapatan dikarenakan sejumlah bayaran yang cukup besar. Semakin lama hubungan auditor dengan klien, maka dikhawatirkan semakin rendah pengungkapan atas ketidakmampuan perusahaan dalam

\section{METODOLOGI PENELITIAN}

Data yang digunakan dalam penelitian ini adalah data sekunder. Metode pengumpulan data dalam penelitian ini menggunakan metode dokumentasi. Data yang dikumpulkan berupa laporan keuangan dari perusahaan manufaktur yang terdaftar pada Bursa Efek Indonesia (BEI) periode 2015 - 2017 yang diperoleh dari tidak dituntut atau telah dituntut kreditor untuk masa kurang dari satu tahun.

3. Perusahaan sedang dalam proses negoisasi restrukturisasi utang yang jatuh tempo

menjaga kelangsungan usahanya di Indonesia peraturan mengenai audit tenure telah diatur didalam Peraturan Pemerintah (PP) Nomor 20/2015 Pasal 11. Peraturan ini menjelaskan bahwa pemberian jasa audit umum atas laporan keuangan dari suatu entitas dilakukan oleh KAP paling lama untuk 5 tahun buku berturut-turut. Auditor dapat menerima kembali penugasan audit untuk klien tersebut setelah 2 tahun buku tidak memberikan jasa audit umum atas laporan keuangan klien tersebut. Auditor juga memiliki dilema untuk memberikan opini audit going concern, dikarenakan besar kemungkinan perusahaan tersebut memilih mengganti KAP yang dapat berefek pada pendapatan KAP.

situs Bursa efek Indonesia atau Indonesian Stock Exchange (IDX), yaitu www.idx.co.id.Populasi dalam penelitian ini adalah seluruh perusahaan manufaktur yang menerbitkan laporan keuangan yang telah diaudit dan terdaftar di Bursa Efek Indonesia (BEI) pada periode 2015 - 2017. Populasi yang digunakan dalam penelitian 
Pengaruh Financial Distress, Debt Default, dan Audit Tenure Terhadap Penerimaan Opini Audit Going Concern Pada Perusahaan Manufaktur Yang Terdaftar Di Bursa Efek Indonesia (BEI) Tahun 2015-2017

ini ialah perusahaan manufaktur yang lengkap yang telah diaudit selama terdaftar di Bursa Efek Indonesia (BEI) periode 2015 - 2017, yaitu sebanyak 144 periode pengamatan, yaitu tahun 2015-2017.

perusahaan. Pemilihan sampel dilakukan berdasarkan metode purposive sampling, yaitu pemilihan sampel perusahaan manufaktur dengan kriteria tertentu. Adapun tujuan dari metode ini untuk mendapatkan sampel yang sesuai dengan kriteria dan kuota yang telah ditentukan. Kriteria penentuan sampel dari penelitian ini sebagai berikut:

a. Perusahaan manufaktur yang terdaftar di Bursa Efek Indonesia (BEI) dan menerbitkan laporan keuangan

b. Perusahaan manufaktur yang tidak keluar (delisting) dari BEI selama periode pengamatan, yaitu tahun 2015- 2017.

c. Perusahaan manufaktur yang mengalami laba bersih komprehensif negatif selama sekurang-kurangnya 1 periode selama tahun pengamatan 2015-2017.

d. Perusahaan manufaktur yang menyajikan laporan keuangannya menggunakan kurs rupiah ( $\mathrm{Rp})$.

Tabel 3

\section{Proses Seleksi Sample Berdasarkan Kriteria}

Perusahaan manufaktur yang terdaftar di Bursa Efek Indonesia per 2017

Perusahaan yang baru terdaftar (IPO) di Bursa Efek Indonesia

selama tahun pengamatan 2015- 2017

Tidak pernah mengalami rugi bersih komprehensif minimal satu

periode laporan keuangan (1 tahun) selama periode pengamatan 2015- 2017.

Perusahaan yang menyajikan laporan keuangannya menggunakan kurs selain rupiah (Rp)

Perusahaan Manufaktur yang layak dijadikan sampel

Sumber : hasil olahan peneliti

Berdasarkan kriteria tersebut, dari 144 perusahaan manufaktur yang terdaftar di BEI didapat 28 perusahaan manufaktur yang dapat menjadi sampel penelitian.
Penelitian ini dilakukan selama 3 tahun pengamatan sehingga jumlah sampel yang akan diteliti adalah sebanyak 84 sampel. Sampel perusahaan dapat dilihat 
pada tabel berikut ini:

Tabel 4 List Sample Perusahaan Manufaktur

\begin{tabular}{|l|l|l|}
\hline No & Stock Code & Nama Perusahaan \\
\hline 1 & AISA & Tiga Pilar Sejahtera Food Tbk \\
\hline 2 & ALKA & Alaska Industrindo Tbk \\
\hline 3 & ALMI & $\begin{array}{l}\text { Alumindo Light Metal } \\
\text { Industry Tbk }\end{array}$ \\
\hline 4 & ALTO & Tri Banyan Tirta Tbk \\
\hline 5 & BAJA & Saranacentral Bajatama Tbk \\
\hline 6 & BIMA & $\begin{array}{l}\text { Primarindo Asia } \\
\text { Infrastructure Tbk }\end{array}$ \\
\hline 7 & BRNA & Berlina Tbk \\
\hline \multicolumn{2}{|l|}{ Sumber : Hasil Olahan Peneliti } \\
\hline
\end{tabular}

Tabel 5 List Sample Perusahaan Manufaktur

\begin{tabular}{|l|l|l|}
\hline No & Stock Code & Nama Perusahaan \\
\hline 8 & BTON & Beton Jaya Manunggal Tbk \\
\hline 9 & FASW & Fajar Surya Wisesa Tbk \\
\hline 10 & GDST & Gunawan Dianjaya Steel Tbk \\
\hline 11 & GJTL & Gajah Tunggal Tbk \\
\hline 12 & HDTX & Panasia Indo Resources Tbk \\
\hline 13 & IKAI & $\begin{array}{l}\text { Inti Keramik Alam Asri } \\
\text { Industri Tbk }\end{array}$ \\
\hline 14 & INAF & Indofarma Tbk \\
\hline
\end{tabular}

Sumber : Hasil Olahan Peneliti

Tabel 6 List Sample Perusahaan Manufaktur

\begin{tabular}{|l|l|l|}
\hline No & Stock Code & Nama Perusahaan \\
\hline 15 & JKSW & $\begin{array}{l}\text { Jakarta Kyoei Steel Work } \\
\text { LTD Tbk }\end{array}$ \\
\hline 16 & JPRS & Jaya Pari Steel Tbk \\
\hline 17 & KBRI & $\begin{array}{l}\text { Kertas Basuki Rachmat } \\
\text { Indonesia Tbk }\end{array}$ \\
\hline 18 & KIAS & $\begin{array}{l}\text { Keramika Indonesia Assosiasi } \\
\text { Tbk }\end{array}$ \\
\hline 19 & KICI & Kedaung Indag Can Tbk \\
\hline 20 & KRAH & Grand Kartech Tbk \\
\hline 21 & MBTO & Martina Berto Tbk \\
\hline
\end{tabular}

Sumber : Hasil Olahan Peneliti 
Tabel 7 List Sample Perusahaan Manufaktur

\begin{tabular}{|l|l|l|}
\hline No & Stock Code & Nama Perusahaan \\
\hline 22 & MLIA & Mulia Industrindo Tbk \\
\hline 23 & MYTX & Apac Citra Centertex Tbk \\
\hline 24 & PSDN & Prashida Aneka Niaga Tbk \\
\hline 25 & SIMA & Siwani Makmur Tbk \\
\hline 26 & SSTM & $\begin{array}{l}\text { Sunson Textile Manufacturer } \\
\text { Tbk }\end{array}$ \\
\hline 27 & TIRT & $\begin{array}{l}\text { Tirta Mahakam Resources } \\
\text { Tbk }\end{array}$ \\
\hline 28 & YPAS & $\begin{array}{l}\text { Yana Prima Hasta Persada } \\
\text { Tbk }\end{array}$ \\
\hline
\end{tabular}

Sumber : Hasil Olahan Peneliti

\section{HASIL DAN PEMBAHASAN}

Penelitian ini menggunakan data sekunder yang diperoleh secara tidak langsung, yaitu melalui data laporan keuangan dari perusahaan manufaktur yang sudah go public dan terdaftar di Bursa Efek Indonesia (BEI). Data laporan keuangan ini didapat melalui website resmi IDX yaitu www.idx.co.id, yang lalu diseleksi dengankriteria dimana laporan keuangan telah diaudit dan memiliki data lengkap, tidak mengalami delisting selama tahun penelitian, disajikan dalam mata uang Rupiah Indonesia, serta mengalami laba bersih komprehensif negatif setidaknya 1 tahun selama periode pengamatan. Proses pemilihan sampel dilakukan dengan menggunakan metode purposive sampling, dimana perusahaan yang layak menjadi sample ialah yang memenuhi kriteria tersebut.

\section{Tabel 8}

\begin{tabular}{l}
\multicolumn{3}{c}{ Proses Pemilihan Sample (purposive sampling) } \\
\hline Perusahaan manufaktur yang terdaftar di Bursa Efek Indonesia per \\
2017 \\
Perusahaan yang baru terdaftar (IPO) di Bursa Efek Indonesia \\
selama tahun pengamatan 2015-2017 \\
Tidak pernah mengalami rugi bersih komprehensif minimal satu \\
periode laporan keuangan (1 tahun) selama periode pengamatan \\
2015- 2017. \\
$\begin{array}{l}\text { Perusahaan yang menyajikan laporan keuangannya menggunakan } \\
\text { kurs selain rupiah (Rp) }\end{array}$ \\
\hline Perusahaan Manufaktur yang layak dijadikan sampel \\
\hline
\end{tabular}

Berdasarkan hasil purposive sampling, perusahaan yang terpilih sebagai sampel adalah 28 dari 144 perusahaan dengan 3 tahun pengamatan sehingga jumlah sampel yang akan diteliti adalah sebanyak 84 sampel. 28 perusahaan yang terpilih 
menjadi sampel penelitian dapat dilihat secara alfabetis dari kode perusahaan. pada Tabel di atas yang sudah diurutkan

Tabel 9

Penerimaan Opini Audit Going Concern

\begin{tabular}{lrrrr} 
& 2017 & 2016 & 2015 & \multicolumn{1}{l}{ Total } \\
\hline GC & 7 & 6 & 5 & 18 \\
\hline$\%$ & $25 \%$ & $21 \%$ & $18 \%$ & $21 \%$ \\
\hline NGC & 21 & 22 & 23 & 66 \\
\hline$\%$ & $75 \%$ & $79 \%$ & $82 \%$ & $79 \%$ \\
\hline Total & 28 & 28 & 28 & 84
\end{tabular}

Berdasarkan analisis data yang dilakukan terhadap laporan auditor independen 28 perusahaan pada tahun 2015 - 2017, secara rata-rata $21 \%$ perusahaan mendapatkan opini going concern dan $79 \%$ perusahaan mendapatkan opini non going concern. Dari hasil analisis diatas dapat diketahui bahwa penerimaan opini audit going concern terbanyak terjadi pada tahun 2017 dan terendah pada tahun 2015.

Tabel 10

\section{Correlation Matrix}

\begin{tabular}{|rl|r|r|r|r|}
\hline & & Constant & ZScore & DD $(1)$ & \multicolumn{1}{c|}{ AT } \\
\hline Step 1 & Constant & 1.000 & -.093 & -.398 & -.721 \\
& ZScore & -.093 & 1.000 & .463 & -.347 \\
DD(1) & -.398 & .463 & 1.000 & -.203 \\
AT & -.721 & -.347 & -.203 & 1.000 \\
\hline
\end{tabular}

Tabel di atas menunjukan hasil dari tabel matriks korelasi dari variabel yang akan diteliti. Tabel hasil matriks korelasi tidak menunjukan gejala multikolinearitas yang signifikan dari variabel independen yang diuji, sebagaimana apabila diamati, korelasi terbesar yang terjadi yakni antara variabel independen financial distress dengan debt default yaitu sebesar 0.463. Namun korelasi terbesar yang terjadi masih lebih rendah dari 0.9 sehingga dapat disimpulkan bahwa tidak terjadi gejala multikolinearitas yang signifikan antar variabel yang akan diteliti. 
Uji Kelayakan Model Regresi

(BEI) Tahun 2015-2017

(Goodness of fit model)

Tabel 11

Hosmer and Lemeshow Test

\begin{tabular}{|l|r|r|r|}
\hline Step & Chi-square & df & Sig. \\
\hline 1 & 4.308 & 8 & .828 \\
\hline
\end{tabular}

Pada tabel di atas merupakan hasil dari uji

tingkat signifikansi uji kelayakan model kelayakan model regresi dengan senilai 0.828 bernilai lebih besar dari _ menggunakan tabel Hosmer and Lemeshow (0.05). Dari hasil perbandingan tersebut Test, dapat dilihat bahwa nilai Chi-Square hitung adalah 4.308 dengan nilai dapat disimpulkan bahwa H0 tidak ditolak signifikansi 0.828. Apabila dibandingkan yang berarti model regresi layak (fit) dan Menilai Keseluruhan Model

(Overall Model Fit)

Tabel 12 Tabel -2 log likelihood (Block Number=0)

Iteration Historya,b,c

\begin{tabular}{|rr|r|r|}
\hline & & & \multicolumn{1}{c|}{$\begin{array}{c}\text { Coefficient } \\
\text { Iteration }\end{array}$} \\
\hline Step 0 & 1 & Log \\
& 2 & 87.646 & -1.143 \\
3 & 87.290 & -1.293 \\
4 & 87.289 & -1.299 \\
& 87.289 & -1.299 \\
\hline
\end{tabular}

b. Initial -2 Log Likelihood: 87.289

c. Estimation terminated at iteration

number 4 because parameter estimates

changed by less than. OO1.

Tabel 4.7 merupakan hasil olah -2 log

likelihood pada (Block Number $=0$ ) adalah likelihood (Block Number=0). Nilai $-2 \log$ 87.289 dengan koefisien konstanta -1.299 
Tabel 13 Tabel -2 log likelihood (Block Number=1)

Iteration Historya,b,c,d

\begin{tabular}{|c|c|c|c|c|c|}
\hline \multirow[b]{2}{*}{ Iteration } & \multirow{2}{*}{$\begin{array}{c}-2 \log \\
\text { likelihood }\end{array}$} & \multicolumn{4}{|c|}{ Coefficients } \\
\hline & & Constant & ZScore & $\mathrm{DD}(1)$ & AT \\
\hline Step 11 & 60.611 & -.967 & -.399 & .897 & -.011 \\
\hline 2 & 47.682 & -.955 & -.975 & .659 & .061 \\
\hline 3 & 43.284 & -.900 & -1.578 & .347 & .207 \\
\hline 4 & 42.644 & -.924 & -1.909 & .219 & .306 \\
\hline 5 & 42.625 & -.937 & -1.977 & .199 & .327 \\
\hline 6 & 42.625 & -.937 & -1.979 & .198 & .328 \\
\hline 7 & 42.625 & -.937 & -1.979 & .198 & .328 \\
\hline
\end{tabular}

Tabel di atas merupakan hasil olah -2 log likelihood pada (Block Number=1) adalah likelihood (Block Number=1). Nilai -2 log 42.625 dengan koefisien konstanta -0.937

Tabel 14 Perbandingan Nilai -2 log likelihood (Block Number=0) dengan -2 log likelihood (Block Number $=1$ )

\section{$-2 \log$ likelihood}

\begin{tabular}{cc}
\hline Block 0 & 87.289 \\
\hline Block 1 & 42.625 \\
\hline
\end{tabular}

Tabel di atas memperlihatkan perbandingan nilai -2 log likelihood (Block Number=0) dengan nilai -2 log likelihood (Block Number=1). Dari tabel tersebut dapat dilihat model regresi yang awalnya memiliki nilai -2 log likelihood 87.289 mengalami penurunan senilai 45.537 setelah dimasukan 3 variabel independen menjadi 42.625 . Penurunan tersebut menunjukan model fit yang lebih baik setelah ada penambahan variabel independen dalam model.

Tabel 15

Hasil Uji Koefisien Determinansi

Model Summary

\begin{tabular}{|l|r|r|r|}
\hline Step & $\begin{array}{c}-2 \text { Log } \\
\text { likelihood }\end{array}$ & $\begin{array}{c}\text { Cox \& Snell } \\
\text { R Square }\end{array}$ & $\begin{array}{c}\text { Nagelkerke R } \\
\text { Square }\end{array}$ \\
\hline 1 & $42.625^{\mathrm{a}}$ & .412 & .638 \\
\hline
\end{tabular}

a. Estimation terminated at iteration number 7 because parameter estimates changed by less than .001 . 

Audit Going Concern Pada Perusahaan Manufaktur Yang Terdaftar Di Bursa Efek Indonesia (BEI) Tahun 2015-2017

menunjukan bahwa nilai Nagelkerke $\mathrm{R}$ variabilitas dari variabel dependen Square adalah sebesar 0.638 , yang berarti dijelaskan oleh variabel-variabel lain diluar variabilitas variabel dependen yang dapat penelitian, sebagai contoh variabel dijelaskan oleh variabel independen adalah pertumbuhan perusahaan dan kualitas audit. sebesar 63.8 persen, sebesar 36.2 persen

Tabel 16 Tabel Uji Klasifikasi

Classification Table

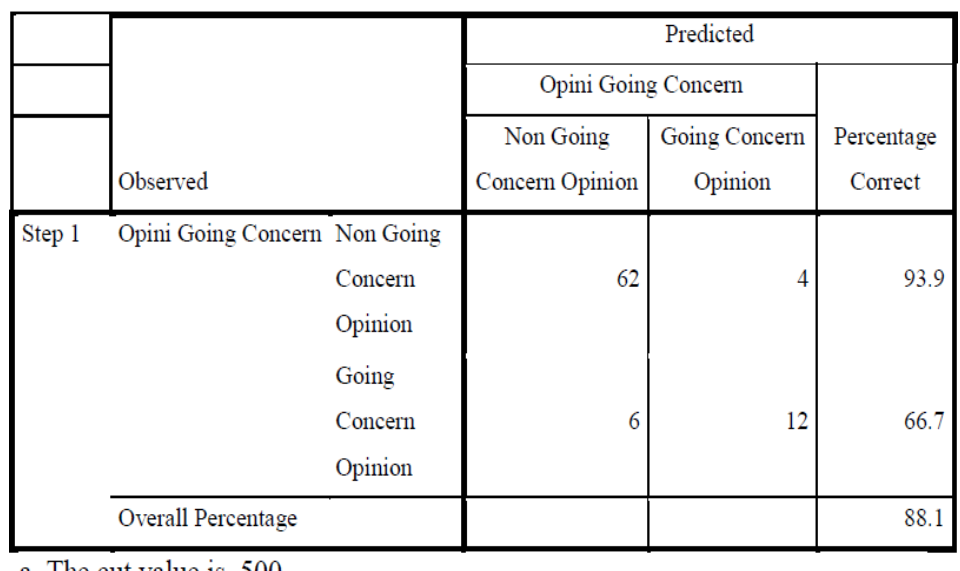

a. The cut value is 500

Berdasarkan hasil tabel di atas dapat dilihat memprediksi probabilitas penerimaan opini bahwa secara keseluruhan kekuatan audit going concern adalah sebesar 88.1 prediksi dari model regresi dapat persen

Tabel 4.17

Hasil Uji Regresi Logistik

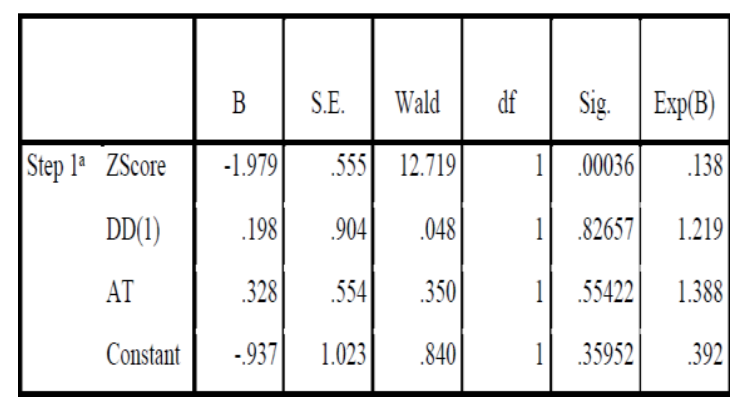

Dari hasil pengujian koefisien regresi

logistik sebagai berikut:

dengan regresi logistik, didapat persamaan

\section{$\mathrm{OGC}=-0.937-1.979 \mathrm{ZS}$ core $+0.198 \mathrm{DD}+0.328 \mathrm{AT}$}

Pengujian hipotesis dilakukan dengan menggunakan regresi logistik untuk menganalisis hubungan antara variabel dependen yaitu opini audit going concern dengan variabel-variabel independen yaitu financial distress, debt default, dan audit tenure. Pengujian ini dilakukan dengan membandingkan nilai tingkat signifikansi hasil pengujian regresi logistik dengan tingkat kesalahan $($ alpha $)=5 \%$. Apabila hasil signifikansi lebih kecil daripada tingkat kesalahan ( sig < alpha) maka H0 
ditolak karena dapat disimpulkan bahwa variabel tersebut memiliki pengaruh yang signifikan (Ha tidak ditolak). Sebaliknya, Apabila hasil signifikansi lebih besar daripada tingkat kesalahan ( sig > alpha ).
Maka H0 tidak ditolak karena dapat disimpulkan bahwa variabel tersebut tidak memiliki pengaruh yang signifikan (Ha ditolak).

Tabel 18 Pengujian Hipotesis - Nilai Sig

\begin{tabular}{|c|c|c|c|c|}
\hline $\begin{array}{c}\text { Variabel } \\
\text { Independen }\end{array}$ & B & Sig. & Hasil Sig. & $\begin{array}{c}\text { Hasil } \\
\mathrm{H} 1,2,3\end{array}$ \\
\hline $\begin{array}{c}\text { Financial } \\
\text { Distress }\end{array}$ & -1.979 & 0.00036 & $<0.05$ & Diterima \\
\hline Debt Default & 0.198 & 0.82657 & $>0.05$ & Ditolak \\
\hline Audit Tenure & 0.328 & 0.55422 & $>0.05$ & Ditolak \\
\hline
\end{tabular}

Tabel di atas memberikan gambaran atas pengujian hipotesis nilai signifikansi dari setiap variabel independen yang diteliti, dijelaskan sebagai berikut :

\section{a) Financial Distress}

Berdasarkan hasil pengujian regresi yang dilakukan, variabel financial distress memiliki nilai signifikansi 0.00036 . Signifikansi financial distress bernilai lebih kecil sehingga dapat disimpulkan variabel independen ini memiliki pengaruh signifikan terhadap variabel dependen dalam penelitian (H1 diterima). Dari hasil regresi tersebut juga didapat nilai konstanta -1.979 yang berarti financial distress memiliki pengaruh negatif terhadap penerimaan opini audit going concern.

\section{b) Debt Default}

Berdasarkan hasil pengujian regresi yang dilakukan, variabel debt default memiliki nilai signifikansi 0.82657 . Signifikansi debt default bernilai lebih besar sehingga dapat disimpulkan variabel independen ini tidak memiliki pengaruh signifikan terhadap variabel dependen dalam penelitian (H2 ditolak). Dari hasil regresi tersebut juga didapat nilai konstanta 0.198 yang berarti debt default memiliki pengaruh positif terhadap penerimaan opini audit going concern.

\section{c) Audit Tenure}

Berdasarkan hasil pengujian regresi yang dilakukan, variabel Audit Tenure memiliki nilai signifikansi 0.55422 . Signifikansi Audit Tenure bernilai lebih besar sehingga dapat disimpulkan variabel independen ini tidak memiliki pengaruh signifikan terhadap variabel dependen dalam penelitian (H3 ditolak). Dari hasil regresi tersebut juga didapat nilai konstanta 0.328 yang berarti Audit Tenure memiliki pengaruh positif terhadap penerimaan opini audit going concern. 
Pengaruh Financial Distress, Debt Default, dan Audit Tenure Terhadap Penerimaan Opini Audit Going Concern Pada Perusahaan Manufaktur Yang Terdaftar Di Bursa Efek Indonesia (BEI) Tahun 2015-2017

\section{HASIL DAN PEMBAHASAN}

Pengaruh Financial Distress Terhadap

\section{Opini Going Concern}

Financial distress pada penelitian ini diukur dengan menggunakan modelAltman Revised Z-Score. Dari hasil pengujian diperoleh nilai signifikansi 0.00036 dimana lebih rendah dibanding dengan alpha dan nilai koefisien variabel -1.979. Dari hasil nilai regresi tersebut dapat disimpulkan bahwa variabel financial distress memiliki pengaruh signifikan negatif terhadap penerimaan opini audit going concern. Pengaruh negatif ini diartikan hubungan nilai Z-Score dengan penerimaan opini audit going concern berbanding terbalik, dimana semakin besar nilai Z-Score perusahaan maka semakin kecil kemungkinan perusahaan mendapat opini audit going concern dan berlaku sebaliknya. Salah satu peninjauan variabel dari sampel yaitu pada tahun 2017 PT Inti Keramik Alam Asri Industri Tbk. memiliki nilai Z-Score -3.3443 sehingga mendapat opini going concern.

\section{Pengaruh Debt Default Terhadap Opini}

\section{Going Concern}

Debt default pada penelitian ini diproksikan dengan menggunakan dummy variabel, yang dikategorisasikan berdasarkan nilai current ratio perusahaan. Hasil dari pengujian diperoleh nilai signifikansi 0.82657 dimana lebih tinggi dibandingkan alpha dan memiliki nilai konstanta 0.198 sehingga dapat disimpulkan variabel independen ini tidak berpengaruh signifikan terhadap penerimaan opini going concern, tetapi memiliki arah pengaruh positif terhadap penerimaan opini going concern. Arah positif ini berarti status debt default dapat sejalan dengan penerimaan opini audit going concern, dimana apabila perusahaan mendapat status debt default maka semakin besar kemungkinan perusahaan menerima opini audit going concern dan sebaliknya.

\section{Pengaruh Audit Tenure Terhadap Opini}

\section{Going Concern}

Audit Tenure merupakan lama perikatan suatu perusahaan dengan KAP yang sama. Dalam penelitian ini dilakukan pengukuran berdasarkan observasi pada laporan audit. Hasil dari pengujian diperoleh nilai signifikansi 0.55422 dimana lebih tinggi dibandingkan alpha dan memiliki nilai konstanta 0.328 sehingga dapat disimpulkan variabel independen ini tidak berpengaruh signifikan terhadap penerimaan opini going concern, tetapi memiliki arah positif terhadap penerimaan opini going concern. Arah positif ini berarti bahwa semakin lama waktu perikatan perusahaan dengan KAP akan meningkatkan kemungkinan penerimaan opini audit going concern. 


\section{SIMPULAN}

Penelitian ini didasari oleh teori agensi dimana auditor dinilai sebagai pihak yang akan menyelaraskan konflik kepentingan dan asymmetry information yang terjadi. Pengujian data empiris dilakukan untuk mengetahui pengaruh financial distress, debt default, dan audit tenure terhadap penerimaan opini audit going concern. Dari hasil pengamatan selama 3 tahun yakni dari tahun 2015 - 2017, diperoleh 28 sampel yang akan diteliti sesuai periode pengamatan sehingga jumlah unit analisis sama dengan 84. Berdasarkan analisis hasil penelitian dan pembahasan yang telah dilakukan maka dapat diambil kesimpulan sebagai berikut :

1. Berdasarkan pengujian yang dilakukan dengan menggunakan regresi logistik, didapatkan bukti empiris bahwa variabel financial distress memiliki arah pengaruh positif yang signifikan terhadap penerimaan opini audit going concern. Hasil penelitian ini menunjukan bahwa semakin besar nilai Z-Score maka akan semakin kecil kemungkinan perusahaan menerima opini audit going concern dan berlaku sebaliknya.

2. Berdasarkan pengujian yang dilakukan dengan menggunakan regresi logistik, didapatkan bukti empiris bahwa variabel debt default tidak memiliki pengaruh signifikan terhadap penerimaan opini audit going concern. Apabila ditinjau kembali maka variabel ini memiliki hubungan yang positif, yang berarti efek status default sejalan dengan penerimaan opini going concern. Atas hasil penelitian yang tidak signifikan peneliti berpendapat bahwa dalam pemberian opini audit going concern, auditor tidak hanya menilai kemampuan perusahan membayar kewajiban yang akan jatuh tempo dalam waktu dekat, akan tetapi lebih mengarah kepada kemampuan perusahaan untuk membayar seluruh kewajiban.

3. Berdasarkan pengujian yang dilakukan dengan menggunakan regresi logistik, didapatkan bukti empiris bahwa variabel Audit Tenure tidak memiliki pengaruh signifikan terhadap penerimaan opini audit going concern. Apabila ditinjau kembali maka variabel ini memiliki hubungan yang positif, yang berarti semakin lama perikatan audit dilakukan semakin besar kemungkinan opini going concern dikeluarkan. Atas hasil penelitian yang tidak signifikan peneliti berpendapat bahwa lamanya perikatan auditee dengan KAP membantu auditor untuk dapat lebih memahami ruang lingkup bisnis dan 
Pengaruh Financial Distress, Debt Default, dan Audit Tenure Terhadap Penerimaan Opini Audit Going Concern Pada Perusahaan Manufaktur Yang Terdaftar Di Bursa Efek Indonesia (BEI) Tahun 2015-2017

memberikan penilaian yang lebih akurat terkait pemberian opini audit

\section{Saran}

Berdasarkan hasil analisis penelitian yang telah dilakukan dan keterbatasan yang ada dalam penelitian ini, maka penelitian selanjutnya disarankan :

1. Bagi penelitian selanjutnya, diharapkan dapat menggunakan seluruh perusahaan yang terdaftar di BEI dan periode penelitian yang lebih panjang untuk memberikan gambaran secara menyeluruh dan meningkatkan keakuratan penelitian.

2. Bagi para investor, diharapkan untuk lebih menyadari akan pentingnya

\section{DAFTAR PUSTAKA}

Altman, E. (1968). Financial ratios, discriminant analysis and the prediction of corporate bankruptcy. 589-609. The journal of finance, 23 (4), 589-609.

Astuti, I. R., \& Darsono. (2012). Pengaruh Faktor Keuangan Dan Non Keuangan Terhadap Penerimaan Opini Audit Going Concern. Diponegoro Journal Of Accounting,vol. 1, 1-10.

Azizah, \& Anisykurlillah. (2014). Pengaruh Ukuran Perusahaan, Debt Default, dan Kondisi Keuangan Perusahaan Terhadap Penerimaan Opini Audit Going Concern. Accounting going concern.

opini audit going concern dalam pengambilan keputusan dan mengumpulkan informasi dan mempertimbangkannya sebelum mengambil keputusan investasi

3. Bagi para auditor, diharapkan agar dapat lebih mengembangkan pertimbangan kondisi-kondisi yang mungkin mempengaruhi kelangsungan usaha perusahaan baik kondisi keuangan maupun nonkeuangan

Analysis Journal, 533-542. Accounting Analysis Journa, 533542.

Chen, K. C., \& Church, B. K. (1992). Default on Debt Obligation and the Issuance of Going-Concern Report. Auditing, 30-49.

Elmawati, D., \& Yuyetta, E. N. (2014). Pengaruh Reputasi Kantor Akuntan Publik (KAP), Audit Tenure, dan Disclosure Terhadap Penerimaan Opini Audit Going Concern. 1-10. Diponegoro Journal of Accounting Volume 3, Nomor 2 ISSN (Online): 2337-3806, 1-10.

Ghozali, I. (2013). Aplikasi Model Analisis 
Data Kuantitatif dengan Program SPSS Edisi Ketujuh. Semarang: Badan Penerbit Universitas Diponegoro.

Handhayani, N. W., \& Budiartha, I. K. (2015). Pengaruh Size, Profitabilitas, Loan to Deposit Ratio dan Kecukupan Modal Terhadap Penerimaan Opini Audit Going Concern. E-Jurnal Akuntansi Universitas Udayana 11.3 ISSN : 2302- 8556, 771-787.

Harris, R., \& Meiranto, W. (2015). Pengaruh Debt Default, Disclosure, Opini Audit Tahun Sebelumnya, Ukuran Perusahaan, Dan Opinion Shopping Terhadap Penerimaan Opini Audit Going Concern. Diponegoro Journal Of Accounting Volume 4 Nomor 3 ISSN : 2337-3806, 1-11.

Imani, G. K., Nazar, M. R., \& Budiono, E. (2017). Pengaruh Debt Default, Audit Lag, Kondisi Keuangan, dan Opini Audit Tahun Sebelumnya Terhadap Penerimaan Opini Audit Going Concern. . e-Proceeding of Management : Vol.4, No.2 Agustus ISSN : 2355-9357, 1676-1683.

Irfana, M. J., \& Muid, D. (2012). Analisis Pengaruh Debt Default, Kualitas Audit, Opinion Shopping dan Kepemilikan Perusahaan Terhadap Penerimaan Opini Audit Going Concern. Diponegoro Journal of
Accounting Volume 1 Nomor 2, 1 10.

Januarti, I. (2009). Analisis Pengaruh Faktor Perusahaan, Kualitas Auditor, Kepemilikan Perusahaan terhadap Penerimaan Opini Audit Going Concern. 1-26. Jurnal SIAE (System Informasi, Auditing, Etika Profesi), $1-26$.

Listantri, F., \& Mudjiyanti, R. (2016). Analisis Pengaruh Financial Distress, Ukuran Perusahaan, Solvabilitas, dan Profitabilitas Terhadap Penerimaan Opini Audit Going Concern. 163-175. Jurnal Manajemen dan Bisnis MEDIA EKONOMI Volume XVI, No.1 Januari 2016, 163-175.

Muttaqin, A. N., \& Sudarno. (2012). Analisis Pengaruh Rasio Keuangan Dan Faktor Non Keuangan Terhadap Penerimaan Opini Audit Going Concern. Diponegoro Journal of Accunting Vol.1.No.2, 1-13.

Nursasi, E., \& Maria, E. (2015). Pengaruh Audit Tenure, Opinion Shopping, Leverage dan Pertumbuhan Perusahaan Terhadap Penerimaan Opini Audit Going Concern pada Perusahaan Perbankan dan Pembiayaan yang go public di Bursa efek indonesia. Jurnal JIBEKA VOL 9 no 1, 37-43.

Praptitorini, M. D., \& Januarti, I. (2011). 
Analisis Pengaruh Kualitas Audit,

Debt Default, Dan Opinion

Shopping Terhadap Penerimaan

Opini Going Concern. Jurnal Akuntansi Dan Keuangan Indonesia 8.1, 78-93. Jurnal Akuntansi Dan Keuangan Indonesia 8.1, 78-93.

Rabuisa, W. F., Runtu, T., \& Wokas, H. (2018). Analisis Laporan Keuangan Dalam Menilai Kinerja Keuangan Perusahaan Pada Bank Perkreditan Rakyat (BPR) Dana Raya Manado. Jurnal Riset Akuntansi Going Concern 13(2), 325-333.
Sugiyono. (2013). Metodologi Penelitian Kuantitatif, Kualitatif, Dan R\&D. Bandung: Alfabeta.

Syahputra, F., \& Yahya, M. R. (2017). Pengaruh Audit Tenure, Audit Tenure, Opini Audit Tahun Sebelumnya dan Opinion SHopping Terhadap Penerimaan Opini Audit Going Concern Pada Perusahaan Manufaktur Yang Terdaftar di Bursa Efek Indonesia Tahun 2013 - 2015. Jurnal Ilmiah Mahasiswa Ekonomi Akuntansi (JIMEKA) Vol.2 No.3, 3947. 